\title{
"Hijos de la madre chingada" or New Mestiza: Paz and Anzaldúa
}

Danielle Lamb

University of Alberta, Canada

\begin{abstract}
This paper explores Chicano/a identity through the seminal work of Octavio Paz and Gloria Anzaldúa. Paz and Anzaldúa draw from a common ethnogenesis and the figure of La Malinche. However, Anzaldúa not only challenges Paz's view on identity but also provides an alternative to his highly gendered theories of the Mexican diaspora.
\end{abstract}

[Keywords: Chicano, identity, Paz, Anzaldúa, diaspora]

...My people called me Malintzín Tenépal the Spaniards called me Doña Marina

I came to be known as Malinche and Malinche came to mean traitor. they called me-chingada

¡Chingada!

(Ha- Chingada! Screwed!)

Of noble ancestry, for whatever that means, I was sold into slavery by MY ROYAL FAMILY—so that my brother could get my inheritance. ...

But Chingada I was not. Not tricked, not screwed, not traitor.

For I was not traitor to myselfI saw a dream and I reached it. Another world...... la raza. la raaaaaaaa-zaaaa.... —by Carmen Tafolla

The last two lines, of Carmen Tafolla's poem referring to "la raza," signify the beginning of Mexicans as we know them today. Mexican history and mythology often portrays La Malinche as a traitor, the woman who sold out her country to Hernán Cortéz and the Spanish conquistadores, rather than a woman who took destiny into her own hands as the poem above implies. These different interpretations of La Malinche are an attempt to determine and define Mexican identity, and ostensibly reflected in Octavio Paz's The Labyrinth of Solitude. Paz offers a reflection on and implicit comparison between Mexicans and those living in the diaspora, namely the pachuco. Gloria Anzaldúa's Borderlands/La Frontera: The New Mestiza challenges Paz's pachuco, offers a new method to

Rupkatha Journal on Interdisciplinary Studies in Humanities (ISSN 0975-2935), Vol 2, No 3, 2010

URL of the Issue: http://rupkatha.com/v2n3.php

URL of the article: http://rupkatha.com/V2/n3/NewMestizaPazandAnzaldua.pdf

(C) www.rupkatha.com 
conceptualize identity, and proposes the new mestiza. She takes up the issue of language as a site of struggle; reclaims the Mexican female cultural figures; deals with the psychology of oppression against Chicanos/as, women and lesbians; and offers a new understanding of how we look at borders. For Anzaldúa the border is more complex than a physical line that divides two nations; rather it is psychic, social and cultural terrain that occupies our minds. While there is a lot of scholarship written on both Paz and Anzaldúa, few critics have compared their works in terms of La Malinche, borders and the diaspora. I will draw on Borderlands/La Frontera to argue that Anzaldúa's theory for Chicano/a identity politics is more inclusive than that of Paz. Mexicans living in the diaspora struggle to locate and situate themselves not only in their new homeland but also in the consciousness of their past, navigating through linguistic and culture hybridity. Despite the contradictions and universality of her work, Anzaldúa provides an alternative theoretical framework to analyze Chicano/a literature.

Borderlands/La Frontera is a unique text in that it uses different genres such as essays, poetry, prose, and memoirs exploring identity; weaves together a multitude of languages; and draws on Anzaldúa's experience as Chicana, a woman, a lesbian, and an activist to simulate the hybridity of the Chicano/a identity. Isabel Durán explains, "In this context, personal memory becomes a political intervention when the metaphors of hybridity, border crossing, transculturation, and mestizaje become a space from which the Chicana experience negotiates the reconstruction of the 'self"' (135). Anzaldúa's Borderlands/La Frontera refuses stasis.

In this way her work parallels that of Paz, whose Labyrinth of Solitude perplexes both readers and critics who seek to pinpoint it as history, philosophy, psychology or art. Jesús Chavarría remarks that the Labyrinth belongs to the poet and suggests it be "approached through its use of imagery, symbolism, metaphor, and paradox" (383). Paz explores the complex subjectivity that does not fit into the orthodox paradigm of national, cultural or religious identity and claims that solitude has captured the Mexican people leaving them trapped within this labyrinth. Paz writes with a certain authority, clarity, and confidence to represent national identities of Mexicans and Mexicans living in the United States, others feel that his work contains a certain youthful naiveté.

Paz draws from Sigmund Freud's psychoanalytical interpretation of history of civilizations to investigate the traumas, repression, and unconscious anxieties that exist within the Mexican consciousness and Samuel Ramos's Profile of Man and Culture in Mexico. The 1934 text marks the first attempt to define and discover Mexican cultural identity, and is both a psychological study and a suggestion of how Mexican culture can find harmony with the rest of the world. What interests Ramos is the multiple aspect of Mexican life: self-denigration, imitation, inferiority and pedantry. According to Ramos: 
Mexicans have been imitating for a long time, without actually realizing that they were imitating. They have always sincerely believing that they were bringing civilizations into national existence. Mimesis is an unconscious phenomenon that reveals certain characteristics of mestizo psychology. It is not the vanity of a foreign culture that has bought about imitation. The unconscious tendency has been rather to conceal the absence of culture not only from foreign eyes but from out own. (18)

$\mathrm{Paz}$ is equally concerned about the inferiority that exists deep within the conscious of the Mexican, which he dates back to the conquest, colonization and colonial servitude.

Bernal Díaz del Castillo's eyewitness account of the conquest of Mexico is described in his work History of the Conquest of New Spain. Most of the entries are written soon after events took place, however other entries draw on second and third hand hearsay. In his manuscript he details the early childhood of Malintzín, who came to be known as La Malinche and Doña Marina, and describes how Malintzín's father and mother were chiefs and Caciques in a small town called Paynala and when her father died, Malintzín's mother remarried another Cacique with whom she had a son. Díaz del Castillo's journal reads:

So that there should be no impediment to this, they gave the girl, Doña Marina, to some Indians from Xicalango, and this they did by night so as to escape observation, and they then spread the report that she died, and as it happened at this time that a child of one of their Indian slaves died they gave out that it was their daughter and the heiress who was dead. The Indians of Xicalango gave the child to the people of Tabasco and the Tabasco people gave her to Cortéz [...] (50)

Díaz del Castillo explains how Malintzín became a key strategist, both a cultural mediator and translator for the Spanish. He writes, "without the help of Doña Marina we could not have understood the language of New Spain and Mexico" (51). He speaks at length of the respect that Malintzín had for both the Spanish and the indigenous people, and how not long after joining the Spanish, she became convinced of her divine role in the conquest.

While Díaz del Castillo's account of Malintzín is recorded at the time of the conquest, many different scholars have hypothesized as to the "true" nature of her involvement. Adelaida R. Del Casillo offers three images of the role of Malintzín in the conquest: an insignificant accomplice to Hernán Cortéz' conquest; synonymous with the destruction of la patria and a scapegoat for all Mexican perdition thereafter; or the misguided and exploited victim of the tragic love affair with Cortéz (122). Yet none of these representations of Malintzín suggests that she was in control of her own destiny. In her essay, "Yo soy la Malinche: Chicana Writers and the Poetics of Ehtnonationalism," Mary Louise Pratt explicates the varying ways Malintzín is symbolized and resymbolized. 
Pratt analyses the poetry of four Chicana writers including Tafolla's "La Malinche," quoted in the epigraph, to put forward that idea that La Malinche was a woman working towards independent (qtd. in Pratt 867-68). Unfortunately, the idea of La Malinche as a self-determining female is seldom acknowledged. Tere Romo explains that La Malinche "has come to 'stand in,' to become 'code' for many negative attributes" and "has been used (and abused) to signify that which is negative in regards to race (i.e., Indian), gender (i.e., female), and class (i.e., conquered people)" (140). For many writers and critics, La Malinche becomes a metaphor for the female traitor, and mother who betrayed her race.

In Mexico, three figures exist of the triad Mexican Mother: the Virgin of Guadalupe, La Llorona, and La Malinche. Paz and Anzaldúa agree with the triad, (although one could argue that Paz would also include Sor Juana Inés de la Cruz) though they both differ in their analysis of the role of La Malinche and the effect that she has had on the consciousness of Mexicans and Chicanos/as. Anzaldúa professes:

La gente Chicana tiene tres madres. All three are mediators: Guadalupe, the virgin mother who has not abandoned us, la Chingada (Malinché), the raped mother whom we have abandoned, and la Llorona, the mother who seeks her lost children and is the combination of the other two. (52)

Anzaldúa draws from myths and historical documents to retrace the history of the three mothers and provides an alternative interpretation to that of Paz and others. Anzaldúa demands that the legacies of these mothers be reinterpreted because casting them aside would only further the denial of the Indian and Mexican past. Anzaldúa traces the figure of La Malinche back to the powerful goddesses of the Aztecs and claims that the male-dominated culture existed even before the time of the conquest. She concludes that these gendered hierarchies sought to weaken the power of the primary creator goddess, Coatlicue by dividing her in two. Tonantsi became the good mother associated with the chaste Virgin de Guadalupe and Tlatzoteotl, the sexual being, La Malinche (Anzaldúa 50). Anzaldúa acknowledges that La Malinche is in some ways the figurative mother of the mestiza race but at the same time she is unable to fully embrace her. There seem to contradictions within Anzaldúa's work because, while she sees La Malinche as the culprit who makes people feel ashamed of their gender and Indian origin, Anzaldúa wants to change these images:

The worst kind of betrayal lies in making us believe that the Indian woman in us is the betrayer. We, indias y mestizas, police the Indian in us, brutalize, and condemn her. Male culture has done a good job on us. Son las acustumbres que traicionan. La india en mí es la sombra: La Chingada, Tlazolteotl, Coatlicue. Son ellas que oyemos lamentando a sus hijas perdidas. (44) 
Anzaldúa seeks to salvage these women through new analysis and "strategically reclaim a space for Mexican female historical presence" (Durán 137).

Unlike Anzaldua who desires to change the image associated with La Malinche, Paz not only embraces the historical images but also constructs her as "la Chingada" and reduces her to a mere object: "The Chingada is even more passive. Her passivity is abject: she does not resist violence, but in an inert heaps of bones, blood and dust. Her taint is constitutional and resides, as we said earlier, in her sex. This passivity, opens the outerworld, causes her to lose her identity" (85-86). Paz refuses to grant La Malinche agency, or even credit her with any foresight or intelligence. As Sheila Marie Contreras points out, "Her status as Native within a racialized sex-gender system positions her at the nexus of at least two discourses of disempowerment: she is multiply removed from institutional power as a woman of the conquered race" (109). Yet, while Paz feels the Mexican identity must be defined in contrast to the negative images, he acknowledges it is difficult to remove such imagery from one's consciousness. Alfred Arteaga explains that, for Paz, La Malinche has a deep psychological effect on Mexicans because it positions them as the "bastard descendents of a sexualized conquest" (24).

La Chingada comes from the Spanish conquest, the making of the Mexican nation-the mixing of Spanish and Indigenous-and violation. Paz explains how the word chingar has many meanings for the Mexican people, ranging from violation to failure and vacillates between poles of the chignón and the chingada. These two terms can be translated into English as "who-fucksover" and the "one-who's-fucked-over" (Arteaga 24). Paz is fascinated and in many ways obsessed with the affects of La Chingada on the Mexican psyche. He writes:

If the Chingada is the representation of the violated Mother, it is appropriate to associate her with the conquest, which was also a violation, not only in the historical sense but also in the very flesh of the Indian women. The symbol of this violation is Doña Malinche, the mistress of Cortez. It is true that she gave herself voluntarily to the conquistador, but he forgot her as soon as her usefulness was over. Doña Marina becomes a figure representing the Indian women who were fascinated, violated, or seduced by the Spaniards. And as a small boy will not forgive his mother if she abandons him to search for his father, the Mexican people have not forgiven La Malinche for her betrayal. (86)

It is because of this violation that Mexicans views themselves as the illegitimate, bastard children of a raped woman. According to Paz, Mexicans blame the Spanish for the initial violation, deem the indigenous inferior, and constantly question the history of their cultural identity. This is problematic for Paz who postulates that, if the Mexican is unable to figure out his identity, he feel inferior and desolate for solitude. 
The first essay in The Labyrinth of Solitude focuses on life in the diaspora, on the other side of the border in North America, a term which Paz uses to refer to namely the United States. He describes the thin line that divides Mexico from the United States when he says, "We can all reach the point of knowing ourselves to be Mexican. It is enough, for example, simply to cross the border" (12). The Mexican and the North American are distinct for Paz, and in North America "even the birds speak English" (Paz 18; Arteaga 95). The Mexican begins to know himself by seeing what he is not. He is not North American. While both Paz and Anzaldúa render the border poetic, Arteaga knows that the border is always a politicized site in which physical and mental borders separates the Chicano/a from the Mexican and the North American.

Anzaldúa uses the metaphor of a scar to draw attention to the pain inflicted by such an unnatural divide in the land: "The U.S.-Mexican border es una herida abierta where the Third World grates against the first and bleeds. And before a scab forms it hemorrhages again the lifeblood of two worlds merging to form a third country-a border culture" (25). She draws from the past to illustrate that the divide is superficial in the sense that the Southwestern United States was once the origin of the Aztecs but today an "open wound" divides the territory-it no longer belongs to Mexico. Keating describes how Anzaldúa's border is both physical and mental:

'Borderlands' is two complex, overlapping yet distinct ways. First, she builds on previous views of the borderlands as a specific geographical location: the Southwest border between Mexico and Texas. Second she redefines and expands this concept to encompass, psychic, sexual and spiritual borders as well. For Anzaldúa, the Borderlands-in both its geographical and metaphorical meanings-represents painful yet also potentially transformational spaces where opposites converge, conflict and transmute. (9-10)

The complexity of the border-physical and psychological-is evident throughout Anzaldúa's work. The physical border to which she refers provides the reader with a deeper understanding of the experience of being Chicano/a and the psychological border draws attention to the anxiety of gender, class, and sexual orientation. Borderlands/La Frontera weaves together Spanish, English, calói, and even Nahuatl to provide a deeper understanding of the complex linguistics of those living on the other side of the border: "People who inhabit both realities are forced to live in the interface between the two, forced to become adept at switching modes" (59). Anzaldúa describes how the language that she speaks at home is different from that which she uses at school. From those who have just arrived from Mexico, she learns the North Mexican dialect, while with her parents and other Chicanos living in the valley she speaks Chicano Texas Spanish (78). There is no one Spanish for Anzaldúa but rather a possibility of 
different hybrid forms, and once Spanish comes in contact with English, like with cross-pollination, new varieties and dialects are created:

Words distorted by English are known as Anglicism or pochismos. The pocho is an anglicized Mexican or American of Mexican origin who speaks Spanish with an accent characteristic of North Americans and who distorts and reconstructs the language according to the influence of English. Tex-Mex, or Spanglish, comes most naturally to me. I may switch back and forth from English to Spanish in the same sentence or in the same word. (Anzaldúa 78)

While most of the words that she uses are simple and often cognates of the same epistemological origin, other words are more difficult to understand for people with limited Spanish knowledge. The use of interlingual hybridized language that Anzaldúa uses replicates the "mode of articulation in the borderland" (Arteaga 36). By writing in both Spanish and English, and all those hybrid possibilities that they avail Anzaldúa invites the reader into her mind, one that is neither Spanish nor English but completely mestiza.

For Paz, this mestizaje and hybridization leads only to disguise, anxiety, conflict and solitude. Mexicans living in North America are different from those in Mexico. Paz is surprised at the fact that these Mexicans living in the United States, who wear the same clothes and speak the same language as the North American, cannot fully be recognized as North American. He refuses to believe that the physical difference, the color of their skin, is what sets the Mexican apart from the North American. The pachuco iii is like a person who disguises him or herself; "feels ashamed of his origins"; moves with "a furtive, restless air" (13); and just as "he does not want to become a Mexican again, he does not want to blend into the life of North America" (14). Loss, disguise, and a sense of inferiority are what lead the pachuco to be cut off from his Mexican conscious but unable to enter into North American society: "The pachuco tries to enter North American society in secret and daring ways, but impedes his own efforts. Having been cut off from his traditional culture, he asserts himself for a moment as a solitary and challenging figure. He denies both the society which he originated and that of North America" (Paz 17). Disguises create internal conflict for the pachuco as he tries to repress his the culture and language of this homeland but at the same time is unable to fully integrate into the diaspora. So while on the one hand, "everyone agrees in finding something hybrid about him, something disturbing and fascinating," Paz considers the pachuco "a pariah, a man who belongs nowhere" (16, 17; Arteaga 96).

The pachuco reveals to Paz the extreme form of solitude that can and does exist. This solitude is more profound than the sense of inferiority. Paz writes, "It is impossible to equate these two attitudes: when you sense that you are alone, it does not mean that you are inferior, but rather that you feel different" (19). Many critics have scrutinized Paz' faulty representation of the pachuco males (Chabram-Desnerseian 276) and the fact that he never uses the feminized 
version of the pachuco. Instead Paz concludes that the pachuco consciousness, like the adolescence consciousness, goes through a process of self-discovery, self-realization, and reflection. However, because the pachuco wants to distance himself from the Mexican and the North American, he must navigate a labyrinth. The pachucho can only escape from this solitude through violence. Chavarría insinuates, "Violence becomes a beatifying experience, for his salvation depends on communion, on his becoming part of every society that he denies" (886). Paz concludes that in the end the pachuco is destined for solitude.

Anzaldúa writes back to Paz' gendered pachuco, Mexicanos, and hijos to address the exclusion of women in his work. Despite the fact that in Spanish, the masculine noun can encompass both male and female subjects, Paz never uses the feminized pachuca, Mexicanas or hijas. This is problematic even considering the time in which he writes. Feminine nouns like la raza and la mestiza in the work of Anzaldúa respond to Paz's obsession of masculine nouns. Readers unfamiliar with Spanish however may have difficulty to differentiate when Anzaldúa is referring to la mestiza to mean Chicanos/as, women, lesbians or all hybrid identities. The ambiguous gender of the word mestiza can be seen in the following: "Let's try it our way, the mestiza way, the Chicana way, the woman way" (110). The reader is aware that Anzaldúa is introducing the new raza mestiza, a hybrid race that includes everyone. Yet at times it is difficult to differentiate.

Anzaldúa's "La conciencia de la mestiza/Towards a New Consciousness" reads like a call for action, a process to "uncover our true faces, our dignity, and self-respect" (108). The political and psychological situation of the mestiza can only change by taking off the masks and removing disguises. Anzaldúa claims:

The struggle has always been inner, and is played out on the outer terrains. Awareness of our situation must come before inner changes, which in turn come before change to society. Nothing happens in the 'real' world unless it first happens in the images of our heads. (109)

It is important that the Chicanos/as becomes aware of their past, and not let others write their history but instead take action into their own hands. Unlike the Chicano movement of the 1960s, which used violence as a means of drawing attention to the political, economic and social inequalities, Anzaldúa sees language as a better alternative to violence. The new mestizas have to look inside themselves, identify their needs, and voice them. They must "gather the splintered and disowned parts of la gente mexicana" and take ownership (Anzaldúa 110). It is only through recognition that every part of the body is valued and useful that the new mestiza consciousness be fully born.

La raza mestiza, "una mezcla de rasas de color-la primera raza síntesis del globo" draws from José Vasconcelos' raza cosmíca a synthesized mystical race (Anzaldúa 99). Vasconcelos, the Mexican philosopher, writer, politician, 
and educator, is without doubt one of the most controversial figures in the social and political history of Latin America. Although he spent a good part of his life either in voluntary or compulsory exile, the impact of his work is still widely studied and discussed today. Vasconcelos' ideas like those of other Latin Americans-Uruguayan philosopher José Enrique Rodó, the Nicaraguan poet Rubén Darío, and Cuban writer José Martí-at the beginning of the century were charged with anti-North American feeling. Vasconcelos felt that Latin Americans should reject imitating American culture and celebrate their own strengths and virtues. His utopian cosmic race exalted and privileged mestizaje and the raza mestiza. Vasconcelos attempt to situate Latin America as the favored race is problematic, and thus it is difficult to understand why Anzaldúa uses his theory to situate the origin of her raza mestiza.

Anzaldúa's raza mestiza, like Vasconcelos' raza cosmíca, is an attempt to include all people. Anzaldúa makes the assumption that everyone is mixed, hybrid, and mestiza. Arteaga further problematises this when he states, "Anzaldúa embraces nearly everyone as potential subject of the new consciousness, for nearly everyone is marginalized in some way" (35). Even the metaphor that Anzaldúa uses comparing the new mestiza to corn, which requires cross-pollination to survive, echoes Vasconcelos' idea that only la raza mestiza will continue to exist. The raza mestiza is an attempt to provide an alternative to the hyphenated Mexican-America, the Hispanic, the pocho or the half-breed but instead it becomes a catch all for everyone.

Despite the universality, and contradictions within Anzaldúa's theory, the new mestiza provides an alternative to Paz' gendered pachuco for Chicanos/as. The new mestiza must break down the duality of subject-object because according to Anzaldúa the future will belong to those who are able to break down the paradigms, and those who straddle two or more cultures. The new mestiza takes off a mask to uncover the mestiza consciousness to look at issues of identity. Stuart Hall provides two definitions of cultural identity: "one, shared culture, a sort of collective "one true self'" and the other a "deep and significant difference," which he derives from Jacques Derrida's notion that meaning is never finished but always open to being deferred (225). The second definition is useful because it addresses shared culture and history, and also acknowledges the unique ways in which identity is always changing.

The new mestiza is defined by the ability to juggle two cultures, to overcome intolerance, and to maneuver among the three cultures. The most important aspect of the new mestiza is the ability to refuse binaries. From this new mestiza, the mestiza consciousness is born. Seemingly aimed at women, it is also the collective consciousness of la raza mestiza. Anzaldúa describes the mestiza's consciousness as a place of psychic restlessness, multiple personality, mental nepantilism, un choque (collision), and counterstance. Despite the state of anxiety that exists within the new mestiza psyche, they must take inventory of 
their historical baggage and not only identify what belongs to what culture, but also what is perhaps no longer needed. It is difficult to differentiate "between 10 heredado, lo aquirado, lo impuesto" but it is only by looking at what has been inherited, acquired and imposed that the new mestiza is able to image the future (Anzaldúa 104). Anzaldúa uses the image of a person looking through a box, getting rid of what not longer has worth and keeping what is useful. She says the new mestiza must " bota lo que no vale, los desimentos, los desencuentos, el embrutacimiento. Aguarda el juicio, hondo y enraizado, de la gente antigua"(104). Looking back to look forward is not easy, it is difficult and at time painful but for Anzaldúa there is no other way for if the new mestiza is to survive.

Through homage to their ancestry, their heritage, their myths, and mother tongue Anzaldúa feels that Chicano/as can reestablish themselves. She traces their origin back to the beginning of the sixteenth century. She explains that "En 1521 nació una nueva raza, el mestizo, el mexicano (people of Indian and Spanish blood) a race that had never existed before. Chicanos, MexicanAmericans, are offspring of those first matings" (Anzaldúa 27). Anzaldúa seeks to draw from collective memory and trauma a new consciousness to look at back to uncover the psychic, social and cultural roots of Chicano/a identity ancestry. Furthermore, she acknowledges the complexity of the Chicano/a identity and seeks to negotiate between the ancient homeland and place from which they reside. Hall, like Anzaldúa recognizes the importance of looking back when he says: "We should not, for a moment, underestimate or neglect the importance of the act of imaginative rediscovery, which this conception of a rediscovered, essential identity entails. 'Hidden histories' have played a critical role in the emergence of many of the most important social movements of our time" (224). While the Chicano/a history shares a similar history with Mexicans, it is also different because unlike the Mexican story of two cultures, the Chicano/a is rooted within the culture of yet another group.

Anzaldúa ends the prose section of Borderlands/La Frontera with a short reflection on growing watermelons with her family in the southwestern United States. She describes how as a family they would go out and plant the seeds in the fertile soil. The soil becomes a metaphor for the birth of the mestiza consciousness. In the same way that the seeds need to be nurtured in order to produce, so too must the new mestiza consciousness be simulated in order to create change. Paul Gilroy uses the seed metaphor to describe the diaspora: "seeds take root in different places. Plants of the same species are seldom absolutely indistinguishable. Soils, nutrients, predators, pests and pollination vary along with unpredictable weather. Seasons change. So do climates" (209). Anzaldúa's the new mestiza provides an alternative to Paz' pachuco and challenges how we think about the multiple identities within the Chicano/a consciousness. 


\section{Notes}

\footnotetext{
' Keating explains that according to Aztec mythology Coatlicue is the earth goddess of life and death as well as the mother of the gods (320). Anzaldúa uses the Coatlicue state to "represent the resistance to new knowledge and other psychic states triggered by intense inner struggle which can entail the juxtaposition and the transmutation of contrary forces as well as paralysis and depression" (Keating 320). For more information see "Entering in the Serpent" in Borderlands/La Frontera: The New Mestiza.

ii Spanish slang used within the pachuco culture during the first half of the 20th century. Today it is also used to refer to a mixing of Spanish and English.

iii The term is used in California to describe "the ungrateful Mexican who denies his Mexican background although he carries it in his blood, and in his actions he tries to ape the present masters of the region" (Leal 115). The term today can be used to describe anyone of Mexican origin living in the United States.
}

\section{Works Cited}

Anzaldúa, Gloria. Borderlands/La Frontera: The New Mestiza. $3^{\text {rd }}$ ed. San Francisco: Aunt Lute, 2007.

Arteaga, Alfred. Chicana Poetics: Heterotexts and Hybridities. Cambridge: Cambridge UP, 1997.

Chabram-Desnerseian, Angie. "En-countering the Other Discourse of Chicano-Mexicano Difference." Cultural Studies 13.2 (1999): 263-89.

Chavarría, Jesús. "A Brief Inquiry into Octavio Paz' Laberinto of Mexicanidad." The Americas 27.4 (1971): 381-88.

Contreras, Sheila Marie. Blood Lines. Austin: U of Texas P, 2008.

Del Castillo, Adelaida R. "Malintzín Tenepal." Chicana Feminist Thought. Ed. Alma M. Garcia. New York: Routledge, 1997. 122-26.

Díaz del Castillo, Bernal. The History of the Conquest of New Spain. Ed. David Carrasco. Albuquerque: New Mexico UP, 2008.

Durán, Isabel. "The Brown/Mestiza Metaphor, or the Impertinence against Borders." Border Transits: Literature and Culture across the Line. Ed. Ana Ma Manzanas. Amsterdam: Rodopi, 2007, 119-45.

Gilroy, Paul. "Diaspora." Paragraph 17.3 (1994): 207-12.

Hall, Stuart. "Cultural Identity and Diaspora." Identity: Community, Culture, Difference.

Ed. Jonathan Rutherford. London: Lawrence and Wishart, 1990, 223-37.

Keating, AnaLouise. The Gloria Anzaldúa Reader. Ed. AnaLouise Keating. Durham: Duke UP, 2009.

Paz, Octavio. The Labyrinth of Solitude. Trans. Lysander Kemp. New York: Grove Press, 1961.

Pratt, Mary Louise. "Yo soy la Malinche: Chicana Writers and the Poetics of Ethnonationalism." Callaloo 16.4 (1993): 859-73.

Ramos, Samuel. Profile of Man and Culture in Mexico. Trans. Peter G. Earle. $3^{\text {rd }}$ ed. Austin: $U$ of Texas P, 1962. 
Romo, Tere. "La Malinche as Metaphor." Feminism, Nation and Myth: La Malinche. Ed. Rolando Romero and Amanda Nolacea Harris. Houston: Arte Público Press, 2005. 139-53.

Tafolla, Carmen. "La Malinche." Canto al Pueblo. San Antonio: Penca Books, 1978.

Vasconcelos, José. The Cosmic Race: Bilingual Edition. Trans. Didier T. Jaén. $2^{\text {nd }}$ ed. Baltimore: John Hopkins UP, 1997.

Danielle Lamb is a PhD candidate in the University of Alberta, Canada. Email: dlamb@ualberta.ca 